\title{
Peningkatan Kemampuan Kompetensi Matematika Pendidikan Dasar Melalui Pendekatan Investigasi Berbantuan Manipulatif
}

\author{
Agus Susanta \\ Program Magister Pendidikan Dasar Universitas Bengkulu \\ agussusanta@unib.ac.id
}

\begin{abstract}
Mathematical competence abilities of elementary education students play an important role in the success of learning mathematics in elementary schools. The purpose of this study was to describe an increase in students' understanding of mathematical concepts through a manipulative assisted investigative approach. The research subjects were students of the first semester elementary teachers education postgrade students who took Elementary education mathematics courses in the 2019/2020 academic year. This research is a classroom action research using data collection methods in the form of observation and tests results. Furthermore, the data were analyzed using data reduction and data triangulation. The results showed that the application of investigative learning increased the ability to understand deep mathematical concepts. The manipulative assisted mathematical investigative approach increases students in carrying out exploration, making assumptions, and making conclusions.
\end{abstract}

Keywords: investigation, manipulative, mathematical competence

\section{Pendahuluan}

Mata kuliah pendidikan matematika dasar dengan bobot 2 sks mengkaji materi, bagaimana pembelajarannya, dan mengkaitkan aplikasinya pada bidang bidang luar matematika. Menguasai secara mendalam tentang konsep, fakta, prinsip, dan prosedur matematika sekolah, sehingga mampu menyusun bahan ajar sesuai dengan model pembelajaran yang digunakan. Kemampuan merumuskan, menggunakan dan menafsirkan matematika dalam konteks nyata merupakan kemampuan kompetensi matematika yang diperlukan bagi seorang guru dalam mengajar. Termasuk di dalamnya bernalar secara matematis dan menggunakan konsep, prosedur, fakta, dan alat matematika dalam menjelaskan serta memprediksi fenomena. 
Hasil refleksi terhadap pembelajaran mata kuliah matematika pendidikan dasar pada program magister pendidikan dasar pada tahun ajaran 2018 menunjukkan bahwa kemampuan mahasiswa tentang content knowledge dan pedagogical content knowledge masih rendah. Hal ini ditunjukkan dengan salah satu pemberian tes pembagian dua pecahan, $\frac{1}{4}: \frac{2}{3}$, bahwa semua mahasiswa mampu menentukan hasil bagi dengan benar, tetapi hampir semua merereka tidak mampu menjelaskan proses penyelesaian dalam merepresentasikan atau menafirkan pembagian dalam konteks nyata. Dalam kasus ini mahasiswa tidak cukup hanya memahami konsep materi matematika secara murni tetapi juga membutuhkan pengetahuan, wawasan, keterampilan, dan kreativitas untuk mampu menyelesaikan masalah secara nyata.

Salah satu alternatif pendekatan pembelajaran yang dapat meningkatkan kemampuan kompetensi matematika mahasiswa, melalui pembelajaran pendekatan investigasi matematika. Beberapa penelitian sebelumnya, Baily (2014) menujukkan partisipasi dalam investigasi matematika yang sebelumnya kesulitan dalam proses perjalanannya menjadi efektif dalam membelajarkan matematika. Selanjutnya Abrar (2015) menyatakan investigasi matematika merupakan suatu kegiatan mengeksplorasi dimana siswa lebih diberi kesempatan untuk memikirkan, mengembangkan, dan menyelidiki hal-hal yang menarik yang mengusik rasa ingin tahunya. Tujuan penelitian ini untuk mengetahui peningkatan pemahaman konsep matematika mahasiswa melalui pendekatan investigasi berbantuan manipulatif.

Investigasi matematika merupakan opend problem matematika yang memungkinkan berbagai cara untuk dieksplorasi secara matematika. Karateristik matematika investigasi berbeda dengan kelas matematika tradisional. Kelas matematika investigasi diharapkan menjadi penemu pengetahuan matematika dan matematika dipandang sebagai aktivitas manusia (Freudenthal, 1991). Siswa diharapkan untuk memutuskan jawaban dan metode mereka yang mendukung, berkomunikasi dengan dan membantu orang lain dalam pembelajaran mereka (Boaler, 2002, 2008). Pilihan dan otonomi menjadi ciri ruang kelas investigasi.

Investigasi berbeda dengan pemecahan masalah. Pemecahan masalah adalah kegiatan yang konvergen, memiliki tujuan yang pasti - solusi dari masalah. Investigasi matematika di sisi lain lebih merupakan aktivitas yang berbeda. Dalam investigasi matematika, siswa diharapkan untuk mengajukan masalah mereka sendiri setelah eksplorasi awal dari situasi matematika. Pembelajaran melalui investigasi matematika memungkinkan siswa untuk belajar tentang matematika, terutama sifat dari aktivitas dan pemikiran matematika. Ini juga membuat mereka menyadari bahwa belajar matematika melibatkan intuisi, eksplorasi sistematis, dugaan dan penalaran, dan bukan tentang menghafal dan mengikuti prosedur yang ada. Tujuan akhir dari penyelidikan matematis adalah mengembangkan kebiasaan berpikir matematis siswa. Yeo, Y.B.W (2017) menyatakan Investigasi matematika sebagai proses, dapat terjadi keduanya investigasi terbuka dan tugas problem solving.

J Nitko (2001) menyatakan bahwa untuk menilai kemampuan investigasi siswa perlu persyaratan kemamapuan: a) Mampu membuat estimasi dan dugaan sebelum mengumpulkan data; b) Mengumpulkan data, menganalisis, dan menampilkan hasil analis; c) Membuat kesimpulan yang sesuai dengan fakta yang diperoleh; d) Menyatakan asumsi dan mengidentifikasi kemungkinan kesalahan dari metode atau data yang dikumpulkan; dan e) Mengkomunikasikan hasil temuan secara efektif hasil investigasi. 
Manipulatif adalah objek (benda) yang didesain untuk mewakili secara ekplisit dan konkret idea matematika yang abstrak. mereka dapat berupa visual dan tactile appeal dan dapat dimanipulasi oleh pembelajar melalui pengalaman hands-on. Thomson 1992 mengemukakan, aktif menggunakan materi manipulatif memberikan kesempatan siswa untuk mengembangkan imaginasi yang dapat digunakan untuk berpikir manipulasi konsep yang abstrak. Penemuan beberapa penelitian menunjukkan bahwa siswa yang menggunakan manipulatif selama pembelajaran matematika tidak unggul (Sowell, 1989; Suydam, 1986). Namun beberapa studi menunjukkan tingkat pencapaian hasil belajar siswa berelasi dengan pengalaman guru mengggunakan manipulatif. (Sowell, 1989; Raphael dan Washington, 1989). Penelitian lain fokus pada efektifitas penggunaan manipulatif pada siswa dengan tingkat kemampuan yang berbeda beda.

Manipulatif bisa membantu sebagai alat untuk guru mentranslate antar abstraksi ke dalam suatu bentuk yang mamapu pembelajar menghubungkan pengetahuan baru kedalam pengetahuan yang ada. Hal ini perlu guru memandu siswa mentranslate antara repesentasi dalam bentuk objek matematika, tindakan dan konsep abstrak sehingga siswa dapat melihat hubungan antara pengetahuan yang dia miliki dengan dengan pengetahuan barunya. Meskipun nampaknya sesuatu yang mudah bagi guru, tetapi kenyataanya tidak mudah. Ini suatu tantangan bagi guru untuk (1) menginterpretasi reperesntasi siswa dalam berpikir matematis, (2) menjawab dan mewakili hubungan antara ide matematika dan, (3) mengembangkan kontek konkret yang cocok untuk belajar matematika Moyer (2001). Sejalan dengan Baily (2014) dalam penelitian tentang Mathematical Investigations for Supporting Preservice Primary Teachers Repeating a Mathematics Education Course, menunjukkan bahwa menggunakan pendekatan investigasi mendukung pemikiran guru pra-jabatan yang mengulang dan belajar tentang matematika telah menghasilkan beberapa perubahan positif. Moyer (2001) dalam penelitian tentang Are we having fun yet? How teachers use manipulatives to teach mathematics, menunjukkan bhawa guru menggunakan manipulatif lebih mnyenangkan dalam pembelajaran matematika.

\section{Metode}

Metode penelitian menggunakan rancangan penelitian tindakan kelas (Classroom Action Research), melalui langkah-langkah perencanaan, pelaksanaan , observasi, refleksi. Ssubjek penelitian adalah mahasiswa S2 Pendidkan dasar Semester I yang mengabil mata kuliah Matematika Pendidikan dasar pada tahun akademik 2019/2020. Jumlah mahasiswa sebanyak 22 orang, mereka ada yang sudah menjadi guru mengajar di kelas dan mahasiswa yang belum mengjar.

Data penelitian dilkukan dengan teknik observasi, dan tes hasil belajar. Observasi dilakukan untuk mengamati kondisi proses belajar mengajar, yang dilihat dari aktifitas mahasiswa dalam menerapkan investigasi, mengajukan masalah, dan menyelesaikan masalah. Tes disetiap akhir siklus digunakan untuk mengetahui kemampuan kompetensi matematika. Data kemampuan matematika dianalisis dengan dilihat rata-rata skor ideal dan, standar devisi idealnya. berisi penjelasan tentang bagaimana penelitian dilakukan, terutama bagaimana penelitian dilaksanakan, termasuk mencakup bagaimana data dikumpulkan, dianalisis, dan disajikan. Metode penelitian untuk artikel pada jurnal ini berupa kajian secara empiris yaitu pengumpulan data di lapangan lalu diolah, dianalisis, ditafsirkan dan disimpulkan. 


\section{Hasil}

Penelitian ini dilaksanakan dalam dua siklus. Pada setiap siklus mahasiswa mempelajari matematika melalaui pendekatan investigasi berbantuan manipulatif. Dalam pembelajarannya Mahasiswa diberikan soal terbuka, berdiskusi, dengan melibatkan manipulatif. Melalui investigasi mahasiswa melakukan ekplorasi, memecahkan masalah, dengan bertanya, mengajukan hipotesisi, merefikasi data, mengajukan ide dan merumuskan pertanyaan untuk diselidiki.

Pelakasanaan siklus I, perkulihan pada materi bilangan rasional melalui tahapan investigasi diawali dengan memberikan problem terbuka kepada mahasiswa, bagaimana menyelesaikan, melakukan investigasi. Menggunakan lembar tugas mahasiswa dapat melakukan sendiri atau secara kelompok mencoba menyelesaikan tugas yang diberikan. Diberikan problem, " Berapa cara berbeda membagi selembar kertas persegi panjang menjadi dua bagian yang sama besar?". Dengan cepat mahasiswa mendapatkan tiga cara berbeda, dan tidak ada lebih dari 3 cara. Setelah di berikan dugaaan bahawa lebih dari 3 cara, kemudian mahasiswa melakukan eksplorasi dan mahasiswa tidak langsung mendapatkan jawabannya. Melalaui diskusi dan beberapa kali mencoba mahasiswa mendapatkan jawaban 4 cara, 5 cara, dan akhirnya bisa tak hingga cara berbeda membagi menjadi dua bagian yang sama. Selain itu mahasiswa memberikan bervariasi jawaban tidak sekedar penjelasan secara atematika, tetapi juga mengkaitkan dengan nilai seni.

Selanjutnya mahasiswa diberikan problem "Bagaiaman cara menjelaskan pengurangan pecahan $1 / 2$ - 1/3 dengan lebih dari satu cara?" Semua mahasiswa mampu menujukan cara pertama dengan menyamakan penyebutnya kemudian pembilang dikurangkan, cara kedua dengan garis bilangan. Mahasiswa diberikan kertas berpetak mahasiswa dapat mengurang dg cara garis dan gambar. Tetapi cara penyelesaian ini banyak membuat miskonsepsi seperti gambar, seperti menunjukkan $1 / 2$ cukup dengan 2 petak persegi dibagi 2 , dan $1 / 3$ cukup dengan 3 petak persegi bagi 3. Sehingga ketika penyebut 6 semua memberika 6 petak persegi. Jelas bahwa mahasiswa terjadi miskonsepsi pecahan dengan satu unitnya tidak sama.

Kemampuan pemahaman konsep mahasiswa dari hasil tes setelah siklus pertama dapat dilihat seperti pada Tabel. 1 .

Tabel 1 Hasil Tes Kemampuan Kemampuan konsep Matematika Siklus I

\begin{tabular}{lll}
\hline Deskripsi & $\begin{array}{l}\text { kemampuan } \\
\text { Matematika }\end{array}$ & \\
\hline Jumlah mahasiswa 20 orang & - & \\
\hline Nilai terendah & 65 \\
\hline Nilai tertinggi & 80 \\
\hline Total nilai & 1515 \\
\hline Rata-rata nilai & 75,8 \\
\hline
\end{tabular}

Dari Tabel. 1 bahwa pada siklus I kemampuan pemahaman konsep nilai terendah 65, sedangkan nilai tertinggi untuk kemampuan konsep 80. Rata-rata nilai kemampuan pemahaman konsep 75,8.

Dari oservasi pembelajaran memunjukkan, mahassiwa terrlihat sangat serius, dan aktif bekerja dengan menyelesaikan tugas yang diberikan, bahkan tidak terasa menggunakan banyak waktu. Mahasiswa dalam melakukan investigasi, belum memenuhi tahapan ekplorasi secara sistematis, membuat dan menguji dugaan/conjectur, menjelaskan atau mengatur ulang, mengelaborasi dan meringkas. Ketika mahasiswa berdiskusi, mahasiswa memahami dengan masalah yang diberikan. Kemudian melakukan eksplorasi mengumpulkan data sebelum membuat perkiraan atau konjektur, terdapat beberapa mahasiswa belum memahami conjektur atau dugaan dari soal yang diberikan, kemudian diberikan cara menenentukan polanya. 
Pada siklus kedua dilakukan perkuliahan pada materi pengukuran dan geometri. Mahasiswa diberikan masalah masalah "perbedaan luas dan keliling segi banyak". Mahasiswa dibagikan manipulatif pengubinan (persegi satuan) disertai lembar kerja secara berkelompok 2 atau 3 orang mahasiswa. Pada topik pengukuran mahasiswa diberikan problem menyusun ubin dengan aturan syarat satu sisi penuh berimpit dibentuk segi banyak yang mungkin terjadi dengan menggunakan 2 ubin, 3 ubin, 4 ubin, 5 ubin, dan 6 ubin. Dengan semua kemungkinan sususan membentuk segi banyak yang berbeda-beda, kemudian menenetukan, keliling, dan luas, masing masing segi banyak yang ditemukan.

Pertama menggunakan 2 ubin persegi kemudian menyusun segi banyak yang mungkin terjadi yang berbeda, menentukan keliling, luas, dan nama segi banyak terbentuk. Berikutnya menggunakan 3 ubin persegi dengan cara yang sama menyusun segi banyak yang mungkin terjadi yang berbeda kemudian menentukan keliling, luas, dan nama segi banyak. Hal ini dilakukan dengan cara yang sama menggunakan 4 ubin, 5 ubin dan 6 ubin persegi, mahasiswa diminta membentuk segibanyak yang berbeda, kemudian menentukan keliling, luas, dan nama segi banyak yang terbentuk.

Dalam melakukan eksplorasi semakin banyak menggunakan ubin dalam membentuk segi banyak, semakin kesulitan menetukan banyaknya segi banyak yang berbeda, hal ini ditunjukkan oleh setiap kelompok mempunyai jawaban yang berbeda-beda ketika menyusun 5 atau 6 ubin, bahkan nama segibanyaknya juga tidak tahu karena biasa hanya mengenal persei atau persegi panjang. Selanjutnya mahasiswa melakukan ekplorasi berbagai segi banyak yang tebentuk, untuk menetukan luas dan keliling. Di akhir kegitan mahasiswa dapat menemukan luas tiad berubah sesuai jumlah ubin yang digunakan, tetapi berbeda dengan keliling. Kemudian mahasiswa menyalin setiap bentuk dengan segibanyak dan menggambarkan pada kertas bertitik.

Selanjutnya, mahasiswa diberikan diberikan soal terbuka "membangun segitiga yang luasnya sama tetapi ukuran sisi segitiga berbeda". Dengan bantuan menggmabar pada kertas bertitik mahasiswa menggambar sebanyak mungkin segitiga dengan ukuran yang berbdeda-beda. Mula-mula mahasiswa hanya mendapatkan beberapa gambar segitiga yang dimaksud kurang dari 5 segitiga, bahkan begitu diminta menggambar sebanyak 10 buah sudah kesulitan. Tetapi setelah diberikan petunjuk menggambar segitiga dengan memeperhatikan luas dan tingginya tetap, mereka menemukan ukuran yang berbeda-beda dan luasnya tetap. Pada akhirnya mereka dapat menemukan banyak tak hingga segitiga yang dimaksud. Melakukan eksplorasi melalui pengumpulan untuk memperluas cara mendapatkan pola. mempresentasikan hasilnya, mahasiswa kelompok yang lain menanyakan, memberikan alternatif jawaban. Setelah mendapatkan data berbagai ukuran, mereka dapat menemukan bahwa segitiga yang alas dan tingginya sama maka luas segitiga akan tetap sama besarnya.

Tabel. 2 Hasil Tes Kemampuan investigasi dan Kemampuan konsep siklus II

\begin{tabular}{ll}
\hline Deskripsi & $\begin{array}{l}\text { kemampuan } \\
\text { matematika }\end{array}$ \\
\hline Jumlah mahasiswa 20 orang & \\
\hline Nilai terendah & 75 \\
\hline Nilai tertinggi & 90 \\
\hline Total nilai & 1580 \\
\hline Rata-rata nilai & 79 \\
\hline
\end{tabular}

Dari Tabel 2 di atas menunjukkan bahwa nilai rata-rata klas secara kesluruhan kemampuan investigasi 74,6 dan rata-rata kemampuan pemahaman konsep 79 . Hasil observasi mennujukkan mahasiswa terlibat aktif serius dalam melakukan investigasi matematika. Dalam proses investigasi mahasiswa berpeluang 
menyampaikan ide ide sendiri dan kelompok dengan angggota kelompok, kelas diskusi. Nampak mahasiswa merasa lebih bertanggungjawab terhadap pembelajaran diri mereka sendiri. Pemahan relatif bagus dan menadalam tentang proses investigasi yang berhubungan dengan konsep, prinsip matematik

\section{Pembahasan}

Pendekatan investigasi berbantuan manipulatif pada matematika pendidikan dasar memerlukan keterlibatan mahasiswa secara aktif dalam proses menemukan jawabannya. Materi perkuliahan disampaikan tidak secara langsung tetapi melalui proses mahasiswa menemukan jawaban tidak sekedar benar. Sehingga mahasiswa sangat diperlukan perannya dalam keterlibatan pembelajaran sebagaiamana proses pembelajaran yang dilakukan pada siklus pertama maupun sikluas kedua pada penelitian ini.

Dari hasil pengamatan dalam dua sklus pembelajaran menunjukkan bahwa pendekatan investigasi dapat meningkatkan pemahaman konsep, meningkatkan ketrampilan berpikir, menganalisa dan meningkatkan kemampuan memecahkan masalah. Kemampuan mahasiswa dalam melaksanakan investigasi meningkatkan komunikasi diidentifikasi sebagai komponenen utama investigasi matematika. Unsur - unsur dasar pada konten isi dan termasuk fakta, konsep, dan definisi, prosedur dan algoritma dan miskonsep, selain proses investigasi proses analisis dan alasan, proses komunikasi, menggunakan bahasa, notasi dan argumen.

Pendekatan investigasi diberikan dengan soal terbuka, mendorong mahasiswa melakukan penyelidikan secara matematis yang memungkinkan mahasiswa untuk menetapkan seberapa jauh mereka dapat memecahkan masalah. Mereka dapat menggunakan kemampuannya untuk memecahkan masalah yang menantang menjadi termotivasi.

Baik pada siklus pertama maupun siklus kedua, mahasiswa menerapkan berbagai konsep dan keterampilan matematika, mengumpulkan, mengorganisir, dan menganalisis. Investigasi memiliki lebih banyak pendekatan yang menyeluruh dimana banyak konsep matematis dan keterampilan diterapkan secara bersamaan dan saling terkait. Mahasiswa dapat mengatasi kesalahpahaman saat mereka melakukan penyelidikan dengan perbedaan pemikiran dari orang lain.

Investigasi memungkinkan mahasiswa untuk menerapkan pengetahuannya untuk memecahkan masalah sambil mempertahankan pendapatnya melalui proses atau langkah - langkah yang mereka ambil. Perdebatan antar mahasiswa berperan aktif dalam pembelajaran mereka sendiri. Investigasi dapat digunakan untuk menumbuhkan rasa ingin tahu dan eksplorasi.

Investigasi memberikan kelebihan pada mahasiswa dalam hal memperoleh pengetahuan dengan cara menganalisa suatu masalah terbuka. Pada penelitian ini untuk menciptakan pembelajaran menyenangkan dan terdapat interaksi sosial mka investigasi dikembangkan dengan cara mahasiswa bekerja dalam kelompok yang beranggotakan 2 atau 3orang sehingga dapat saling berdiskusi. Selama proses pembelajaran dilakukan, para mahasiswa terlihat sangat serius, dan aktif bekerja dengan menyelesaikan tugas yang diberikan.

Dengan menggunakan pendekatan investigasi pengajaran matematika, mahasiswa diberikan dengan kepuasan berhasil menyelesaikan tugas yang menantang dan mampu mengidentifikasi dan menyelidiki masalah mereka sendiri.

Dari hasil tes kemampuan matematika di akhir siklus, menunjukkan bahwa kemampuan pemahaman konsep matematika lebih tinggi dari kemampuan investigasi matematikannya baik pada siklus pertama maupun siklus kedua.

Dari siklus pertama ke siklus kedua terjadi peningkatan kemampuan konsep matematika sebesar 4,225. \% pada siklus kedua. Dengan demikian pembelajaran dengan pendekatan investigasi dapat meningkatkan pemahaman konsep matematika mahasiswa pada mata kuliah matematika pendidikan dasar. 
Dalam proses investigasi, mahasiswa dapat menggunakan ide-ide awal mereka, bertukar pendapat dengan anggota kelompok dan merancang tindakan selanjutnya. Dosen fokus pada masalah ke arah mengemukakan masalah mengajak mahasiswa melakukan tindakan untuk mengivestigasi dan bukan sekedar mendapatkan jawaban yang benar saja. Melalui investigasi membuat mahasiswa dituntuntut lebih berpikir logis, kreatif, dan kritis dalam menyelesaikan soal pemecahan masalah. Selain itu invstigasi dapat mendukung menemukan hal yang baru dalam matematika yang unik dan menarik, serta dapat menyelesaikan dengan berbagai alternatif cara. Memberi pengetahuan baru dengan soal yang dapat dibuat dan diselesaikan menemukan sendiri konsepnya, sehingga pembelajaran menjadi bermakna, lebih mudah dipahami.pembahasan berisi hasil penafsiran atas hasil penelitian yang telah diperoleh. Bagian ini juga berisi hasil pembandingan antara hasil penelitian dengan teori yang mendukungnya serta temuan penelitianpenelitian lain yang relevan. Hasil pembandingan dengan teori ini dapat terlihat apakah hasil penelitian ini mendukung dan memperkuat teori yang sudah ada atau malah bertolak belakang dengan teori tersebut

\section{Kesimpulan}

Berdasarkan hasil penelitian dan pembahasan dapat disimpulkan sebagai berikut.

1. Penerapan pembelajaran dengan pendekatan investigasi untuk meningkatkan kompetensi mahasiswa pada mata kuliah matematika pendidikan dasar dilakukan melalui pemberian soal terbuka yang memungkinkan untuk melakukan eksplorasi melalui proses matematika melaui Langkah-langkah mengatur data, mencari pola, dugaan, penyimpulan, pembenaran dan penjelasan dugaan dan generalisasi.

2. Melalaui pendekatan investigasi dapat meningkatkan pemahaman konsep yang mendalam, meningkatkan daya ingat, meningkatkan pengetahuan prosedural dan kemampuan berpikir matematis.

\section{Saran}

Berdasarkan hasil penelitian dan pembahasan dapat disimpulkan sebagai berikut.

1. Penerapan pembelajaran dengan pendekatan investigasi untuk meningkatkan kompetensi mahasiswa pada mata kuliah matematika pendidikan dasar dilakukan melalui pemberian soal terbuka yang memungkinkan untuk melakukan eksplorasi melalui proses matematika melaui Langkah-langkah mengatur data, mencari pola, dugaan, penyimpulan, pembenaran dan penjelasan dugaan dan generalisasi.

2. Melalaui pendekatan investigasi dapat meningkatkan pemahaman konsep yang mendalam, meningkatkan daya ingat, meningkatkan pengetahuan prosedural dan kemampuan berpikir matematis.

\section{Referensi}

A,I (2015) Investigasi dalam proses pembelajaran matematika. Jurnal al-Khwarizmi, Volume III, Edisi 2, Oktober 2015, Hal. 57 - 62

Arslan, C. \& Yavus G (2012) A study on mathematical literacy self-efficacy beliefs of propspective teachers. Procedia Social and behaviour sciences $46(2012) 5622-56255$

Baily, J (2014) Mathematical Investigations for Supporting Preservice Primary Teachers Repeating a Mathematics Education Course Australian Journal of Teacher Education. Vol 39, 2, February 2014 
Boaler (2002) Experiencing school mathematics traditional and reform approaches to teaching and their impact in Student learning. Mahwah, NJ. Lawrence Firbaum.

Boaler (2008) Promoting "Relation Equity" and high achievement through an innovatives mixed ability approach. British Educational Research Journal, vol 34 , no 2.

Cankoy, O \& Darbaz, S. (2010). Effect Problem Possing Based on Problem

Solving Instruction on Understanding Problem. Journal of Education 38,

1124. Diperoleh 17)April 2012, dari http: //

efdergi.hacettepe.edu.tr/english/.../OS MAN\%20CANKOY.pdf

Freudenthal, H. 1991. Revisiting Mathematics Education. Netherlands: Kluwer Academic Publishers

J Nitko. (2001). Eductional Assessment of Student. Upper Saddle River, New Jersey. Penerbit Prentice Hal Inc

Moyer. P (2001) Are we having fun yet? How teachers use manipulatives to teach mathematics. Educational Studies in Mathematics 47: 175-197, 2001. ? 2002 Kluwer Academic Publishers. Printed in the Netherland

Silver, E.A., \& Cai.J (1996) An Analysisi of arithmetics problem posing by middle school students. Journal for reseearch in Mathematics Education, 27. Pp. 521532 .

Sowell, (1989) Effect of manipulative materials in mathematics instruction. Journal for research in Mathematics Education, Vol. 20 No. 5 498-505

Suydam, M.N. (1986). Manipulative Materials and Achievement. Arithmetic Teacher, 33(2), pp.83-90.

Thompson, P.W.1992, 'Notations, conventions and constraints: Contributions to effective uses of concrete materials in elementary mathematics'. Journal for Research in Mathematics Education 23(2), 123-147.

Yeo, J. B. W. (2017). Mathematical Investigation: Task, Process, adm Activity. Technical Report ME2009-01 January 2009Mathematics and Mathematics Education National Institute of Education Singapore 